\title{
Economic Stabilization after the Treaty of Trianon: Challenges and Possibilities ${ }^{1}$
}

\author{
Endre DOMONKOS
}

Senior Research Fellow

Budapest Business School, University of Applied Sciences, Faculty of International Management and Business, Department of International Relations, Budapest, Hungary

e-mail: domonkos.endre@uni-bge.hu

\begin{abstract}
The 'Great War' had harmful impacts on Hungary's national economy. With the disintegration of the Austro-Hungarian Monarchy, the former self-sufficient economic unit broke into six different entities, which had far-reaching consequences in Central and Eastern Europe. Economic difficulties were further aggravated by rampant inflation. Finally, the loss of the majority of raw materials by the Treaty of Trianon meant that Hungary was cut off from its sources of supply.

The following paper examines the impacts of economic reconstruction in Hungary. The analysis also focuses on the development of industry, agriculture, and trade in the 1920s.
\end{abstract}

Keywords: economic history, Hungary, Reconstruction Loan, agriculture, industry, trade in the 1920 s

\section{Introduction}

At the end of the First World War, the performance of the Hungarian economy as a result of war efforts - was hardly 40 per cent of the pre-war level. Due to the dismemberment of the Austro-Hungarian Monarchy, Hungary lost its traditional markets. Economic chaos was exacerbated by the requisitions of the Soviet Republic and the Romanian and Serb troops, which occupied a great part of the country. Additionally, by 1918, Hungary was hit by rampant inflation. The territorial detachments of the Treaty of Trianon resulted serious distortions in the economy, whereas the country was compelled to pay war reparations. All these factors paralysed economic life entirely.

1 This paper was presented at the conference Past, Present and Future of Central Europe, organized by Budapest Business School and Sapientia Hungarian University of Transylvania in Cluj-Napoca on 20 November 2020 (online conference). 
In parallel with the consolidation of domestic politics, the main aim of the government led by Prime Minister István Bethlen was to carry out economic and financial stabilization. The measures adopted within the framework of the Reconstruction Loan granted by the League of Nations contributed to the balance of budget. According to Law No. V of 1924, the National Bank of Hungary was created. It had the exclusive right to issue banknotes and was independent from the government. The final step of the monetary reform was the introduction of pengô in 1927, which was tied to the pound sterling.

The objective of the paper is to present the economic reconstruction in Hungary after 1920. Taking into account of the modified external conditions from 1920 onwards, it is important to evaluate the impacts of the stabilization measures in the industry and the agriculture. Because of length constraints, I will not highlight the domestic politics of the Bethlen government and the economic measures introduced in other Central and Eastern European countries.

\section{Economic Difficulties after the Treaty of Trianon and the Effects of Financial Consolidation}

After the Treaty of Trianon (4 June 1920), the framework of the Hungarian economy and external conditions changed substantially, which had direct implications both economically and politically. The problems that Hungary had to face after the 'Great War' were the following:

1. Before 1918, the Hungarian economy was an organic part of the AustroHungarian Monarchy with well-developed food processing industry, based on a customs union and common monetary and pricing system. In the autumn of 1918, the former large and efficient economic unit was dismembered, and six new entities were created in Central and Eastern Europe. Hungary lost its traditional markets and the main industrial regions. Another major problem was that the length of customs frontiers increased to 6-7,000 $\mathrm{km}$ and the number of monetary systems rose from 13 to 27. With the dissolution of the Dual Monarchy, seven new customs areas emerged in the region. Between 1919 and 1924, the Central and Eastern European countries withdrew into isolation, and most of them adopted prohibitive measures in trade (customs tariffs) (Szávai 2009: 114).

2. The Soviet Republic, coupled with political instability, contributed to the economic chaos in Hungary. The nationalization measures of the Hungarian Bolsheviks, which extended to all branches of the economy (agriculture, industry, and trade), further aggravated the economic difficulties in the country. After the collapse of the communist regime, the Romanian and Serbian armies requisitioned not only the agricultural products and livestock but also the rolling stocks and machines. They systematically weakened the economic resources without paying 
any compensation (Gulyás 2012: 12). The first step towards political consolidation was the election of the new legislative body - known as the National Assembly on 15 January 1920. Finally, the election of Miklós Horthy as Regent of Hungary by the National Assembly on 1 March 1920 marked the end of the period of political instability in Hungary's modern history.

3. The Treaty of Trianon with its territorial detachments and population losses further exacerbated the severe economic conditions in the Kingdom of Hungary. Because the majority of raw material resources were annexed to the neighbouring countries (Czechoslovakia, Romania, and the Kingdom of Serbs, Croats, and Slovenes), industrial branches were largely cut off from its sources of supply.

4. Economic exhaustion during the war years led to rampant inflation. In parallel with the deterioration of goods supply, governments resorted to issuing unsecured paper money in order to cover a growing budget deficit. By the end of World War I, money had lost about 60 per cent and by the summer of 1919 more than 85 per cent of its value. From the summer of 1921 to 1924, the volume of banknotes in circulation increased from 17 billion to 2,500 billion crowns. The value of the crown sank to virtually zero (Berend 1985: 267).

As far as inflation was concerned, Aldcroft pointed out its positive impact in stimulating the economic activity and trade. He emphasized that cheap loans and a sharp decline in real wages to less than half of the pre-war level gave a boost to industrial activity and employment. 'The steel, metal and coal industries were especially favoured, while employment and output in manufacturing as a whole rose by about one-third' (Aldcroft 1997: 68). In my opinion, the benefit from inflation was relatively short-lived and did not solve the fundamental problems of the Hungarian economy such as the general shortage of capital and the low level of domestic accumulation.

5. Finally, according to the Treaty of Trianon, Hungary was compelled to pay reparations for 30 years in restitution for the war damages that it had caused. From 1921, approximately 880 tons of coal were to be delivered to Yugoslavia and 28,000 heads of livestock each to Italy, Yugoslavia, and Greece (Romsics 1999: 124). In October 1923, decision was taken about the payment of 200 million gold crown by the Kingdom of Hungary. The Reparations Commission introduced reliefs for the repayment conditions, which were fulfilled by coal deliveries to Yugoslavia up to 1926. The unresolved question of war reparations was a serious burden on the economy and hindered its fast recovery (Berend-Ránki 1976: 271).

The victorious Entente Powers were interested in promoting the economic stabilization of the countries of East Central Europe. One of the most important endeavours was to ensure political and economic stability in the region. This implied the avoidance of the spread of a Bolshevik-type regime, which emerged in Soviet Russia. Keynes stressed in 1921 that international loans were essential 
both to former allies and former adversaries to stabilize their economies (BerendRánki 1977: 89).

The first attempt to reorganize the economy was carried out in the spring of 1920, when the old banknotes were overprinted - all with the word Magyarország 'Hungary' -, and thus the independent Hungarian currency was created. The state used half of the nominal value of all banknotes submitted and debased as a compulsory loan. In order to strengthen the value of the korona, the government decided to stop printing money without the backing of adequate reserves. In parallel with this process, austerity measures were introduced to curb government spending and finance the lowered state expenditures by new taxes. In increasing receipts, the new property tax played a crucial role, which level varied between 5 per cent and 20 per cent for various types of property. Despite the efforts made by Finance Minister Lóránt Hegedüs, the financial reorganization based on domestic resources failed. On 16 September 1921, he resigned, and inflation started to accelerate from the summer of 1922 and reached double figures (Tóth 2005: 501).

The new Finance Minister, Tibor Kállay, strived for the implementation of an 'organic tax reform', whose main aim was to increase taxation income. The new system had a progressive element, but it was designed primarily to spread the tax burden over the broad mass of population, which was rejected by the majority of the Hungarian society. At the same time, he tried to reduce the irrationally high numbers of public employees by 11,000 (from 209,000 to 198,000). These measures led to only partial and transitory success, but they did not improve the precarious economic situation. From the second half of 1922, it became more obvious in government circles and economic institutions that restoring the equilibrium of the budget and stabilizing the currency could only be achieved by obtaining a sizeable international loan (Romsics 1999: 131-132). Austria had already taken up a loan of 650 million gold koronas in the autumn of 1922, in which the country was compelled to renounce the Anschluss with Germany (Németh 2011: 133). Other countries in the region followed the same way to reorganize their economies.

After Hungary had been admitted to the League of Nations on 18 September 1922, the government led by István Bethlen submitted a request for a short-term (40-50 million gold koronas) and a long-term loan (350-650 million gold koronas) in April 1923 in order to obtain an arrangement on reparation charges. After lengthy debates, it succeeded in achieving - with the support of Great Britain and the Little Entente and France - that the international loan could not be burdened by reparations (BerendRánki 1976: 308). In November 1923, the Head of the Financial Committee of the League of Nations, Sir Arthur Salter paid an official visit to Budapest. He discussed with Hungarian politicians the economic situation of the country. During the negotiations, it became clear that economic and financial consolidation could be achieved with the help of three different instruments: to guarantee the sustained balance of the state budget, to halt accelerating inflation, and, finally, with the creation of an independent 
bank, to enjoy the monopoly of note issue. The delegation agreed on the reconstruction package provided by the League of Nations (Péteri 1985: 121-125).

The reconstruction scheme together with Protocols I and II were signed in March 1924, and the National Assembly enacted them in April of the same year. In Protocol I, Hungary's integrity and sovereignty were guaranteed by six countries (Czechoslovakia, France, Great Britain, Italy, Romania, and the Kingdom of Serbs, Croats, and Slovenes). Hungary guaranteed the loyal implementation of the Treaty of Trianon. Protocol II contained the detailed programme of financial stabilization and the tasks of a delegated Commissioner General responsible for the execution of the reconstruction scheme. The Council of the League of Nations entrusted Jeremiah Smith with the supervision of the Hungarian state budget. He vetoed every expenditure that would have jeopardized the implementation of the stabilization programme. If it were necessary, he could levy new taxes (Schlett 2020).

At first, the Little Entente (Czechoslovakia, Romania, and Yugoslavia) and France refused the loan that had been requested by Hungary because they insisted on fulfilling strict economic and political conditions. Britain and Italy stood with Hungary, and as a result of their pressure the League agreed to vote half of the credit applied for (Romsics 1999: 132). An important step in the implementation of the scheme was the issue of the Reconstruction Loan in July 1924 of the nominal amount of USD 68.7 million (307,000,000 gold koronas). The greatest part of the loan (96 per cent) was issued publicly in the United Kingdom, the United States, Italy, Switzerland, the Netherlands, and Sweden. The conditions were less favourable because the nominal rate of interest was 7.5 per cent, except for the Italian portion, which was 8.05 per cent (Nötel 1986: 196). Therefore, in return for the 250,000,000 gold koronas that were actually taken up, more than 600,000,000 had to be repaid over a twenty-year term (Tóth 2005: 502).

The spring of 1924 marked the first step towards economic consolidation. The reconstruction package was implemented by Law No. V of 1924. This required the creation of the National Bank of Hungary, which was independent from the state. The newly established institution managed the state debt and handed over the responsibility for issuing currency. The Bank of England contributed to the capital stock of the National Bank of Hungary, which was 4 million pounds (82 million gold koronas). In return, the exchange rate of the national currency was tied to the pound sterling, one gold korona equalling 17,000 paper koronas. The legal framework of the National Bank was also laid down by the reconstruction programme, which was in compliance with the statute of the Bank of England. From 1924 onwards, the former had the exclusive right to issue of banknotes, conducted the monetary policy of the country, and was responsible for the bills of exchange. It was a state treasury being underwritten by private companies (Kaposi 2002: 280-281).

The monetary reform was completed by the introduction of pengó in November 1925, one pengő equalling 12,500 paper koronas, which was tied to the pound 
sterling (Nötel 1986: 196). Its small coin, the fillér, came into circulation only on 1 January 1927.

The number of state employees was lowered in two stages, in 1924 and 1925, by a further 35,000, which brought the total civil service establishment to approximately 150-160,000, or about half of the pre-war level (Tóth 2005: 502). Schlett rightly noted that state bureaucracy was streamlined, and more emphasis was placed on efficiency and profitability. As a result of the saving measures, the Ministry of Food was closed and the benefits in kind of public servant employees at discount prices were abolished. The price review committees and coal government committee ceased to exist. Finally, red tape was eased by the merger of state authorities and institutions, whereas procedures were also simplified (Schlett 2020).

In order to guarantee the sustained balance of the state budget, the rescue plan contained a progressive taxation system, ranging from 1 to 44 per cent (Kádár 2015: 76-81). Due to the measures (the reduction of public expenditures and the increase of receipts) introduced in the middle of the 1920s, in 1925, the budget closed with a surplus of 63 million gold koronas without drawing on the international credit. As the value of the korona was stabilized, internal equilibrium was restored, and because of the raising demand, tax revenues also increased (Draskóczy et al. 1998: 344). Therefore, more than a third of the international loan was used to maintain the budget in balance. The remainder was applied to various investments. The restructuring of the finances ended officially on 30 June 1926. Hungary regained the control over its public finances because all sequestered revenues were now released and placed at the government's disposal (Romsics 1999: 133).

As far as the Reconstruction Loan was concerned, it restored the confidence of Western creditors to Hungary. This opened the door to a series of private credits. In 1931, the total external debt owed by the country was USD 700 million and its annual service of USD 48 million, which accounted for 6 per cent of the national income and as much as 48 per cent of the export receipts. The per capita debt in Hungary was the highest (USD 83) among the Central and Eastern European countries at this time (Nötel 1986: 224).

In Hungary, similarly to Austria, economic consolidation was successful because inflation was halted by the government, and it established the institutional and legal framework of the Hungarian National Bank. The inflationary spiral was stopped in the middle of 1924 as confidence returned and the exchange rate of the korona was stabilized by linking it to the pound sterling (Aldcroft-Morewood 1995: 39). Tighter budget controls and increasing tax revenues contributed to the balance of the state budget. During the implementation of the stabilization plan, Hungary lost the control over its public finances between 1924 and 1926. The unusually high nominal interest rate (7.5 per cent) of the international loan meant an additional burden for the national economy. 
Table 1. External debt and debt service in 1931 in six Central and Eastern European countries

\begin{tabular}{lccccc}
\hline & \multicolumn{2}{c}{ External debt } & \multicolumn{3}{c}{ External debt service } \\
\hline & Million USD & $\begin{array}{l}\text { USD per head } \\
\text { of population }\end{array}$ & Million USD & $\begin{array}{c}\text { Percentage of } \\
\text { national income }\end{array}$ & $\begin{array}{c}\text { Percentage of } \\
\text { exports }\end{array}$ \\
\hline Bulgaria & 138 & 23 & 10 & 3 & 22 \\
\hline Czechoslovakia & 393 & 27 & 22 & 1 & 5 \\
\hline Hungary & 728 & 83 & 48 & 6 & 48 \\
\hline Poland & 860 & 27 & 58 & 3 & 36 \\
\hline Romania & 1,016 & 56 & 52 & 3 & 36 \\
\hline Yugoslavia & 631 & 45 & 30 & 3 & 23 \\
\hline $\begin{array}{l}\text { Total of six } \\
\text { countries }\end{array}$ & 3,766 & 40 & 220 & 3 & \\
\hline
\end{tabular}

Source: NÖTEL, Rudolf. 1986. International Credit and Finance. In: Kaser, M. C.-Radice, E. A. (eds.), The Economic History of Eastern Europe 1919-1975. Vol. II. Interwar Policy. The War and Reconstruction. Oxford: Clarendon Press. 223.

Although economic and financial consolidation in the mid-1920s was accompanied by bankruptcies both in the state and private sectors and unemployment rose as a result of dismissals in the public administration, labour market had significantly improved in Hungary by 1926 (Szávai 2009: 117). The negative effects of the consolidation process were offset by the restoration of fiscal balances and the growing public and private investments in the national economy.

\section{Industrial Development in Hungary in the 1920s}

The Treaty of Trianon had negative effects on the development of the industry. The uneven distribution of the remaining capacities and the shortage of raw materials were the major problems, which were arisen from the territorial detachments. Hungary's industrial capacities were largely cut off from sources of supply, which now lay beyond its frontiers. According to Teichova, as regards basic materials, Hungary lost access to 83 per cent of crude iron, 84 per cent of timber, 65 per cent of coal, and all of the oil, copper, gold, silver, and salt deposits. Therefore, the imports of raw materials became essential to maintain in operation the metallurgy, engineering, and textile factories (Teichova 1985: 226-227).

Other industrial branches, such as the production of means of transport, including rolling stocks and railway carriages, had substantial overcapacities in the tight domestic market. During the interwar period, the shortage of raw materials meant an obstacle for the Hungarian industry. For instance, the flour milling industry was unable to fully utilize its 6.7 mil tons of capacity from domestic supplies of grain on the diminished territory and could not reach more than 3 mil tons at the best of harvests (Teichova 1985: 227). Another major problem occurred with the 
shrinkage of the domestic market, which coupled with the population's low income level during the interwar period. Due to unfavourable external and internal factors, industrial production in 1920 was only 35-40 per cent of the pre-war level.

There were two important factors which had a profound impact on industrial development in Hungary in the 1920s:

1. Owing to the dismemberment of the Austro-Hungarian Monarchy in the autumn of 1918, Customs Law No. LIII of 1907 was no longer valid, wherefore a completely new customs tariff structure had to be introduced. The new customs tariff system entered into force on 1 January 1925. Its main aim was to protect the development of domestic industry. In Hungary, the 10-20 per cent level formerly prevailing in the Monarchy was replaced by a general tariff of 30 per cent and by one as high as 50 per cent on finished industrial products imported in greater quantities. In the heavy industry, such as the production of means of transport and rolling stocks, the average rate of tariff was 20 per cent. Besides the prohibitions of the early 1920s, the autonomous customs tariff system gave protection in particular to underdeveloped light industries (textiles) that used home-produced materials. At the same time, the import of basic raw materials and agricultural products was not prohibited (Romsics 2017: 117-122).

2. The law that provided state support for industry in Hungary entered into force in 1922. In parallel with the adoption of the new legislation, the majority of the handicraft's representative organizations and trade corporations were reshuffled. Turnover taxes were reduced from 3 to 2 per cent for domestic manufacturers. The state allowed tax exemptions and allowances for factories. In 1928, a long-term credit (50 million pengős) was earmarked for the development of industry (Szávai 2009: 118).

Stabilization measures and the new customs tariffs introduced from 1 January 1925 contributed to the modest economic growth in Hungary in the second half of the 1920s. The main endeavour of the government was to support the development of manufacturing industries. Whereas industry and mining accounted for 25 per cent of the national income in 1913, as a result of territorial changes after 1920, this ratio rose to 31 per cent in 1929, when factory production exceeded 12 per cent of the pre-war level (Romsics 2011: 208).

Within the context of general growth, the situation of various branches of industry showed a mixed picture. The textile industry with its spectacular development became the second largest branch of Hungary's industry, the production of which grew by a factor of ten between 1921 and 1929. Whereas textiles had accounted for only 4.8 per cent of manufacturing output in 1913, this figure was 14.2 per cent in 1929. During the period of 1920-1922, 43 new mills were opened, and 14 acquired major additions of plant and equipment. In the 1920s, textiles absorbed fully one third of all investments in the Hungarian industry, and manpower more than quintupled (from 13,000 to 75,000) (Teichova 1985: 250-252). 
Table 2. Hungarian industrial production by branch in 1913-1938

Percentages of industrial output

\begin{tabular}{lccc}
\hline & $\mathbf{1 9 1 3}^{\mathbf{1}}$ & $\mathbf{1 9 2 9}$ & $\mathbf{1 9 3 8}$ \\
\hline Iron and metal industry & 15.5 & 11.3 & 14.2 \\
\hline Engineering & 13.8 & 10.2 & 9.7 \\
\hline Electric power & 1.5 & 4.2 & 4.4 \\
\hline Building materials & 4.3 & 4.8 & 3.7 \\
\hline Chemicals & 7.8 & 7.4 & 9.7 \\
\hline $\begin{array}{l}\text { Predominantly producers' } \\
\text { goods }\end{array}$ & 42.9 & 37.9 & 41.7 \\
\hline Textiles & 4.8 & 14.2 & 15.3 \\
\hline Clothing & 1.5 & 2.2 & 2.4 \\
\hline Leather & 2.7 & 3.2 & 3.9 \\
\hline Wood & 2.5 & 3.2 & 2.5 \\
\hline Paper & 0.6 & 1.2 & 2.1 \\
\hline Printing & 2.6 & 2.4 & 1.7 \\
\hline $\begin{array}{l}\text { Predominantly consumers' } \\
\text { goods }\end{array}$ & 14.7 & 26.4 & 27.9 \\
\hline Food processing & 42.4 & 35.7 & 30.4 \\
\hline
\end{tabular}

Note: on the 1920 territory, calculated in current prices.

Source: Teichova 1985: 241

Similarly to the production of textiles, timber and paper industry showed a dynamic growth. However, only 22 per cent of the capacities remained within the post-Trianon territory of Hungary; thanks to the liberalization measures introduced in the 1920s, wood processing grew significantly. The output of the paper industry increased by two and a half times throughout the whole period, and several new plants were also established (Kaposi 2002: 289).

The relative predominance of the food processing industry fell within the country's new borders. The main problem was that, due to the Treaty of Trianon, it was not only oversized but also lost the majority of its raw materials and safe markets. Therefore, its share in the industrial production fell from 42 per cent in 1913 to 36 per cent by 1929, but it still remained the most important source of income for the economy. Tight market conditions and increasing competition from abroad hindered the development of the milling industry. The Hungarian milling products were characterized by inelasticity both in costs and prices in the world market. Energy needs of the milling industry also changed during the interwar period because powersupplied mills assumed an even greater role than before (Kaposi 2002: 289-290).

The capacities of sugar refining remained unused in the post-Trianon territory. Former plants were merged or closed. Because the level of domestic consumption was low, exports could be maintained by considerable state subventions, whose costs were covered by high internal prices. For instance, the Hungarian sugar was 35-38 per cent cheaper in Austria, which led to the further contraction of the domestic market (Gunst 2006: 79). 
Some other branches of the food processing industry were capable of developing significantly. Milk production and canning industry, especially the production of fruit and tomato preserves, started to play an exceptionally important role. In 1922, the network of cooperatives was built up, which operated as single production units in order to meet milk processing and distribution needs. Canning factories were located in Budapest, in the Great Hungarian Plain and along the Danube-Tisza Interfluve. The output of vegetables and tinned fruit doubled throughout the whole period, while exports of tomato preserves increased by twentyfold (Gunst 2006: 79). Despite the growth of the new branches, such as canning, chocolate and milk processing, milling output fell because high tariffs meant a loss of foreign markets. Preference given to cane sugar also had negative impacts on the Hungarian sugar beet industry. Finally, the 'declining market for beer, partly caused by cheap wine, brought about some conversion of Budapest breweries to other activities in the food, chemical and textile sectors' (Turnock 2005: 213). The structure of the Hungarian light industry more or less adjusted to the country's new needs.

As far as heavy industry was concerned, a similar reorganization took place after 1920. Due to the lack of reliable markets, the production of agricultural machinery and vehicles were forced to contract. The engineering sector's share of output fell from 13.8 per cent in 1913 to 9.7 per cent by 1929 (Romsics 1999: 135).

Taking into account the difficulties of the 1920s, the production of tractors at the Hofherr Factory could be interpreted as the renewal of the Hungarian engineering industry. Manufacture of automobiles started to gain ground at the Manfréd Weiss Works and at the Hungarian Wagon and Machine Works in Győr, but as a result of tight market and low internal demand, it could not specialize in mass production. Several new types of products managed to strike roots, amongst them motorcycles and bicycles. However, other heavy industrial branches were able to retain their competitiveness in the world market. From 1922 onwards, radio sets were produced by the United Incandescent Lamp and Electrical Co. (Egyesült Izzó és Villamossági Gyár), and its output rose significantly. The patent of the galvanometer by Ottó Bláthy in 1923 gained similar success. It was the Ganz Works that focused on the production of diesel-motor-powered locomotives and sea ships. Nevertheless, these successes were not able to offset the overall decline. Kaposi stated that the Hungarian engineering industry could only develop slowly in the 1920s because it lacked the essential elements of modern technologies applied in the industrialized countries of Western Europe (Kaposi 2002: 293-294).

There were a number of endeavours in the chemical industry in order to adjust to the new post-war situation. Hungária Mútrágya, Kénsav és Vegyiipar Rt. [Hungária Artificial Manure, Sulphuric Acid, and Chemicals PLC] and Péti Nitrogén Müvek [Pét Nitrogen Works], which were established in the 1920s, played an important role by producing artificial fertilizers. Considerable progress was achieved by the factories of Chinoin and Richter Gedeon with their pharmaceuticals, and new 
capacities were created during the interwar period. The total output of the chemical industry was 50-60 per cent higher than the pre-war level, but it could not carve out a leading position (Berend-Ránki 1976: 451).

It is worth mentioning with regard to the ore mining and metallurgical branch that some new blast furnace capacity was built in Diósgyőr in the 1920s, where the necessary inputs could be assembled. Emphasis was given to steel produced from scrap or from imported pig iron. In 1925, the discovery of huge bauxite deposits in the Veszprém region proved to be of major significance. As Turnock stressed, quarrying at Ajka started in 1932, production from scattered fields was delivered by the Halimba railway, and steps were taken in processing, although it was some time before Hungary would create its own aluminium industry (Turnock 2005: 211).

Of the basic industries, electricity generation flourished spectacularly. The generating capacity that was left within the new frontiers in 1921 amounted to 276 million KW, three times more than before the war. In less than a decade, this tripled again (Romsics 1999: 135). Its share in factory output rose from 1.5 to 4.2 per cent over the whole period in question (Honvári 2005: 46).

Besides the negative impacts of the Treaty of Trianon, another major problem during the interwar period was that the bulk of Hungary's industrialization was developed in the area of greater Budapest. This was a characteristic of the country's economy from the late $19^{\text {th }}$ century, and this did not change in the interwar years because 70 per cent of all joint-stock companies, 75 per cent of the total stock capital, nearly half of the labour force, and the majority of productive capacities were located there (Teichova 1985: 259).

\section{Agriculture and Foreign Trade}

Although the share of agriculture in the national income fell from 44 per cent in 1913 to 40 per cent by 1928-29, it preserved its dominance in the national economy. Several authors emphasized the stagnation of crop production, which was only 1-2 per cent above the pre-war level for the following reasons: the inequalities of landownership despite the land reform introduced in 1920; the persistence of pre-war cultivation methods; a neglect of soil conservation measures (Romsics 1999, Tóth 2005).

Political and social motives, rather than economic policy, played a decisive role in the land reform in Hungary. The Land Reform Bill became an urgent task when the Smallholders Party won the majority in the first post-war election (26 January 1920) in order to consolidate the Horthy regime. As a result of the dominant influence and strength of the aristocracy and the landowner class, the most moderate reform was carried out in Hungary in 1920. The total area that was redistributed was no more than 1.2 million cadastral holds, 6 per cent of the arable land of the 
country. The areas held by the great landed estates decreased only 10 per cent and preserved their predominance during the interwar period. In the 1930s, big estates comprised 48 per cent of all arable land in Hungary. From the expropriated land, 400,000 families received small plots altogether, each averaging only one hectare. 250,000 of the claimants had previously been landless, and after the reform - which gave only tiny scattered parcels of land -, they still remained in a semi-agrarian proletarian state. An additional 100,000 hectares of land was used to strengthen the social basis of the new regime, giving estates to former members of the national army headed by Horthy (the so-called vitézi telek) (Berend 1985: 159-160). At the end of the 1930s, approximately 1,500 large estates amounting to 0.1 per cent of the total number of holdings occupied 23.5 per cent of the total cultivated land, whilst 99.9 per cent of holdings between 1 and 50 hectares owned 53.6 per cent of agricultural land. The land reform of Hungary created the largest rural proletariat in Central and South-Eastern Europe. This was shown by the fact that agricultural labourers' and peasants' holdings of less than 1 hectare comprised 52.3 per cent of all active persons in agriculture as against 15.7 per cent in Romania, 15.2 per cent in Yugoslavia, and 9.1 per cent in Bulgaria (Teichova 1989: 900-901).

Table 3. Changes in the distribution of Hungary's agricultural holdings between 1895 and 1935

\begin{tabular}{ccccc}
\hline & \multicolumn{2}{c}{ Farms } & \multicolumn{2}{c}{ Area as \% of total area } \\
\hline Size of farm (acre*) & Number as \% of all farms & 6.0 & 10.1 \\
\hline $0-5$ & 53.7 & 72.5 & 24.2 & 21.8 \\
\hline $5-20$ & 35.3 & 21.3 & 23.4 & 20.0 \\
\hline $20-100$ & 10.0 & 5.4 & 13.4 & 18.2 \\
\hline $100-1,000$ & 0.8 & 0.6 & 33.0 & 29.9 \\
\hline over 1,000 & 0.2 & 0.2 &
\end{tabular}

Note: * Hungarian acre [hold] is 5,755 square metres.

Source: Berend-Ránki 1972: 150

As far as the land reform is concerned, the main problem was that peasant families were unable to cultivate their own lands because the majority of them did not have agricultural equipment and machinery. Two-thirds of them had no animals at all. Besides the unfavourable conditions, the system of compensation was extremely conservative. Whereas peasants had to pay for the land, - generally at 30-40 per cent more than the average market price - the state did not intervene in the purchase (Berend 1985: 160). A significant number of the new landowners were sooner or later bankrupted. Between 1926 and 1938, 67,000 holdings were auctioned, a large part of them being new peasant farms (Pölöskei-Szakács 1962: 634).

The other factor considered a hindrance for agricultural production was the reinforcement of concentration on grain. This happened when the protected grain market of the Monarchy was no longer available to Hungarian agriculture, whilst 
large and growing supplies of grain came onto the international market, primarily by the increase of wheat production in North and South America. The more intensive branches of horticulture and winegrowing hardly expanded. The only positive phenomenon was that the proportion of fallow land fell from 9 to 4 per cent throughout the whole period (Romsics 1999: 136-137).

The input of labour also influenced the productivity of the agriculture. The excess of rural population was a specific problem in Hungary and also in other Central and Eastern European countries between 1920 and 1939. Estimations of Mátyás Matolcsy stated that 24 per cent of the active rural workers were not employable. The ratio was even higher in the case of day-labourers and peasant owners of dwarf properties, who accounted for 34.2 per cent (Ormos 2004: 303).

Soil conservation, which was one the most crucial means to raise yields, likewise stagnated. The use of artificial fertilizers increased from the pre-war level of $12 \mathrm{~kg} /$ hectare to $15 \mathrm{~kg} /$ hectare by the end of the 1920s. At the same time, the most developed western European countries were applying an amount between 100 and $300 \mathrm{~kg} /$ hectare (Tóth 2005: 504). Artificial fertilizers were used mainly by the big estates, while smallholdings hardly applied this farming technology. Agricultural technique was the third important factor which affected the increase of yield. The process of mechanization, which started at the end of the $19^{\text {th }}$ century, further continued in the 1920s. Technological development was coupled with the appearance of tractors in the Hungarian countryside. Berend noted that the first tractors appeared in Hungary in 1912, but by 1925 their number reached 1,189 and by 1928 6,000. The old steam threshers were also partly replaced by modern combustion engine threshers, numbering 5,700 in 1925 and 9,200 in 1928 (Berend 1985: 166). Despite positive achievements, mechanization did not affect transportation, storage, and hoeing. They were largely carried out using manual or animal power.

Table 4. Crop production in Central Europe in the periods of 1903-1912 and 1934-1938

\begin{tabular}{lcccccccccc}
\hline Country & \multicolumn{2}{c}{ Wheat } & \multicolumn{2}{c}{ Rye } & \multicolumn{2}{c}{ Corn } & \multicolumn{2}{c}{ Potatoes } & \multicolumn{2}{c}{ Sugar beets } \\
\hline & $(1)$ & $(2)$ & $(1)$ & $(2)$ & $(1)$ & $(2)$ & $(1)$ & $(2)$ & $(1)$ & $(2)$ \\
\hline Austria & 14 & 17 & 14 & 15 & 15 & 26 & 83 & 137 & 242 & 260 \\
\hline Czechoslovakia & 15 & 17 & 15 & 16 & 5 & 21 & 91 & 135 & 260 & 290 \\
\hline Hungary & 13 & 14 & 12 & 11 & 18 & 20 & 80 & 73 & 254 & 210 \\
\hline Bulgaria & 11 & 13 & 8 & 10 & 13 & 12 & 38 & 61 & 129 & 160 \\
\hline Yugoslavia & 9 & 11 & 8 & 8 & 13 & 18 & 41 & 62 & 195 & 190 \\
\hline Romania & 11 & 10 & 9 & 9 & 13 & 10 & 75 & 77 & 205 & 150 \\
\hline Poland & 12 & 15 & 11 & 13 & 11 & 14 & 103 & 138 & 243 & 270 \\
\hline
\end{tabular}

Notes: Crop yield figures are given in quintals per hectare.

(1) = yearly average for 1903-1912

(2) = yearly average for 1934-1938 
The average production of the most important crops was slightly better than the pre-war level. The yields of sugar beet increased by 51 per cent, but the harvest of grain, barley, and potato rose by 38, 25, and 21 per cent respectively, which was higher than the average (between 6 and 10 per cent). The growth of average yields was between 11 and 26 per cent, but only four of the seven main crops surpassed the 1913 level. After 1929, agriculture was characterized by stagnation (Rab 2009: 140).

As far as livestock is concerned, only a moderate progress was achieved compared to the pre-war level. Cattle and sheep stocks lagged behind the pre-war level in 1929 by 15 and 36 per cent respectively, while horse and pig numbers remained constant (Berend 1985: 170). The number of livestock did not increase, but this was compensated by qualitative improvements. Sheep breeding declined, which could be explained by the shrinkage of fertile meadows and the devastations of World War I. Poultry farming was dominant in the interwar years, which made up 1012 per cent of Hungary's total exports. The ratio of livestock deteriorated slightly compared to the fertile area, but its quality improved over the whole period in question (Rab 2009: 140-141).

Hungary relied heavily on foreign trade in the interwar years. The country's economic structure depended on the export of agricultural products that required access to new markets. Foreign currency earnings were essential for import substitution, which was based on the protection of domestic manufacturing industries. In the 1920s, our biggest foreign trade partner was Austria, which took up 44 per cent of Hungarian total exports in 1923. The bulk of exports comprised agricultural products, whereas imports mainly consisted of manufactured goods. From 1926 to 1929, the second most important partner was Czechoslovakia with a share of 18 per cent, followed by Germany, which accounted for 12 per cent of our export and in return delivered metals, machines and equipment, dyestuffs and textiles. Although trade relations developed between Hungary and Italy in the first half of the 1920s, our total exports and imports were not more than 5 and 3 per cent respectively (Kaposi 2002: 294-295).

\section{Conclusions}

At the end of the First World War, the Hungarian economy was hit by rampant inflation, which was a concomitant of economic exhaustion. The dismemberment of the AustroHungarian Monarchy together with the territorial detachments of the Treaty of Trianon meant additional losses. Furthermore, Hungary was compelled to pay war reparations, which was a serious burden on the economy and hindered its fast recovery.

One of the most important endeavours of the government led by István Bethlen was to achieve economic and financial consolidation. Thanks to the loan of the League of Nations, fiscal balance was restored, and inflation was halted. At the same 
time, the National Bank of Hungary was established, which became independent from the government and had the exclusive right to issue banknotes and conduct the monetary policy of the country. The monetary reform was completed by the introduction of the pengő in 1927. The new currency was tied to the pound sterling. Stabilization measures also involved the introduction of a progressive taxation system in order to guarantee the sustained balance of the state budget. The Reconstruction Loan played an important role by creating favourable conditions for growth and investments.

After 1920, the circumstances of industrial development changed significantly in the post-Trianon territory. Owing to the Treaty of Trianon, Hungary's industrial capacities were largely cut off from sources of supply which laid beyond its frontiers. Therefore, the bulk of heavy industrial branches (metallurgy and engineering) depended on imports of raw materials, whereas other sectors, such as the production of means of transport, including rolling stocks and railway carriages, had substantial overcapacities in the tight domestic market. The shrinkage of domestic market together with the uneven distribution of industrial capacities further exacerbated the prevailing difficulties in the post-war years.

Agriculture was hit severely by the dismemberment of the Austro-Hungarian Monarchy and the territorial detachments of the Treaty of Trianon. The most fertile soils, including the territories of Bačka, Banat, and Csallóköz, were ceded to the neighbouring countries. Foreign exchange earnings of agricultural export were necessary to meet Hungary's import needs during the interwar period. Although agricultural output reached the pre-war level in 1923, price changes of farm products were unfavourable for peasant holdings in the 1920s, which reflected the unfavourable gap between agrarian and industrial prices. As the prices of agricultural products declined in the world market, Hungary suffered a significant deterioration in its terms of trade. From 1928, due to the collapse of international market accompanied by the downturn in wholesale prices in the domestic market, agriculture had to face serious difficulties.

\section{References}

ALDCROFT, Derek Howard. 1997. Inflation, Currency Depreciation and Reconstruction in Europe. In: Aldcroft, Derek Howard (ed.), Studies in the Interwar European Economy. Aldershot, Hants, England: Ashgate, Edward Elgar Publishing Limited. 53-88.

ALDCROFT, Derek Howard-MOREWOOD, Steven. 1995. Inflation, Reconstruction, and Stabilization. In: Aldcroft, Derek Howard-Morewood, Steven (eds.), Economic Change in Eastern Europe since 1918. Aldershot, Hants, England: Edward Elgar Publishing Limited. 22-42. 
BEREND, T. Iván. 1985. Agriculture. In: Kaser, Michael Charles-Radice, Edward Albert (eds.), The Economic History of Eastern Europe 1919-1975. Vol. I. Economic Structure and Performance between the Two Wars. Oxford: Clarendon Press. 148-209.

1987. Válságos évtizedek [Critical Decades]. Budapest: Magvető.

BEREND, T. Iván-RÁNKI, György. 1972. A magyar gazdaság száz éve [One Hundred Years of the Hungarian Economy]. Budapest: Kossuth/Közgazdasági és Jogi Kiadó. 1976. Közép- és Kelet-Európa gazdasági fejlödése a 19-20. században [Economic and Social Development of East Central Europe in the $19^{\text {th }}$ and $20^{\text {th }}$ Centuries]. Budapest: Közgazdasági és Jogi Könyvkiadó.

1977. East Central Europe in the $19^{\text {th }}$ and $20^{\text {th }}$ centuries. Budapest: Akadémiai Kiadó.

DRASKÓCZY, István-BUZA, János-KAPOSI, Zoltán-KÖVÉR, György-HONVÁRI, János. 1998. Magyarország gazdaságtörténete a honfoglalástól a 20. század közepéig [Hungary's History from the Conquest to the Middle of the $20^{\text {th }}$ Century]. Revised edition. Budapest: Aula.

GULYÁS, László. 2012. A Horthy-korszak külpolitikája 1. Az elsó évek: 1919-1924. [Foreign Policy of the Horthy Era 1. The First Years: 1919-1924]. Máriabesnyő: Attraktor.

GUNST, Péter. 2006. Magyarország gazdaságtörténete 1914-1989 [Economic History of Hungary between 1914 and 1989]. Budapest: Nemzeti Tankönyvkiadó.

HONVÁRI, János. 2005. Magyarország gazdaságtörténete Trianontól a rendszerváltásig [Economic History of Hungary from Trianon to the Change of Regime]. Budapest: Aula.

KÁDÁR, Béla. 2015. Trianontól a győri programig [From Trianon to the Győr Programme]. Rubicon 3: 76-81.

KAPOSI, Zoltán. 2002. Magyarország gazdaságtörténete 1700-2000 [Economic History of Hungary, 1700-2000]. Budapest-Pécs: Dialóg Campus.

NÉMETH, István. 2011. Az első Osztrák Köztársaság (1918-1938): történeti áttekintés [The First Austrian Republic, 1918-1938: Historical Overview]. In: Németh, István-Fiziker, Róbert (eds.): Ausztria a 20. században. Az „életképtelen” államtól a „Boldogok szigetéig” [From the "Unviable' State to the "Island of the Happy']. Budapest: L'Harmattan. 128-147.

NÖTEL, Rudolf. 1986. International Credit and Finance. In: Kaser, Michael CharlesRadice, Edward Albert (eds.), The Economic History of Eastern Europe 19191975. Vol. II. Interwar Policy. The War and Reconstruction. Oxford: Clarendon Press. 170-287.

ORMOS, Mária. 2004. A gazdasági világválság magyar visszhangja [The Repercussions of the Great Depression to Hungary]. Budapest: Polgart.

PÉTERY, György. 1985. Montagu Norman és a magyar „szanálási mû”. Az 1924es magyar pénzügyi stabilizációról [Montagu Norman and the Hungarian 
'Reconstruction Scheme'. On the Hungarian Financial Stabilization in 1924]. Századok 119(1): 121-125.

PÖLÖSKEI, Ferenc-SZAKÁCS, Kálmán. 1962. Földmunkás és szegényparaszt mozgalmak Magyarországon 1848-1948 II. [Poor Peasants and Country Worker Movements in Hungary]. Budapest: Mezőgazdasági és Erdészeti Dolgozók Szakszervezete.

RAB, Virág. 2009. A mezőgazdaság [The Agriculture]. In: Gulyás, László (ed.): A modern magyar gazdaság története. Széchenyitöl a Széchenyi tervig [The Contemporary Economic History of Hungary. From Széchenyi to the Széchenyi Plan]. Szeged: JATE Press. 125-141.

ROMSICS, Ignác. 1999. Hungary in the Twentieth Century. Budapest: CorvinaOsiris.

2011. A 20. század rövid története [Short History of the Twentieth Century]. Rubicon Könyvek. Second, revised edition.

2017. A Horthy-korszak [The Horthy Era]. Budapest: Helikon.

SCHLETT, András. 2020. „Ínségköltségvetés” - Megszorító csomag az 1920-as években ['Restrictive Budget'. Austerity Measures in the 1920s]. Archívnet 20(45): https://archivnet.hu/insegkoltsegvetes-megszorito-csomag-az-1920-evekben. Retrieved on: 29 March 2021.

SZÁVAI, Ferenc. 2009. A Horthy-korszak gazdasági élete, 1920-1945 [The Economic Life of the Horthy Era, 1920-1945]. In: Gulyás, László (ed.), A modern magyar gazdaság története. Széchenyitól a Széchenyi tervig [The Contemporary Economic History of Hungary. From Széchenyi to the Széchenyi Plan]. Szeged: JATE Press. 113-122.

TEICHOVA, Alice. 1985. Industry. In: Kaser, Michael Charles-Radice, Edward Albert (eds.), The Economic History of Eastern Europe 1919-1975. Vol. I. Economic Structure and Performance between the Two Wars. Oxford: Clarendon Press. 222-323.

TÓTH, György István. 2005. A Concise History of Hungary: The History of Hungary from the Early Middle Ages to the Present. Budapest: Corvina-Osiris.

TURNOCK, David. 2005. The Economy of East Central Europe, 1815-1989. Stages of Transformation in a Peripheral Region. London-New York: Routledge. 